\title{
BELÉM DO PARÁ, MACEIÓ, E A SOBREVIVÊNCIA DOS “PORTADORES DO MODELO DE ARQQUITETURA"
}

\author{
Artur Simões Rozestraten*
}

\section{Resumo}

Este artigo apresenta pesquisa em andamento, apoiada pelo CNPq e pela Pró-reitoria de Pesquisa da Universidade de São Paulo, sobre as interações entre as expressões dos promesseiros do Círio de Nazaré, em Belém do Pará, dos "brincantes" do auto-natalino do Guerreiro Alagoano e o universo dos modelos arquitetônicos, entendidos como objetos com formas arquitetônicas e escala reduzida. Este estudo trata, mais precisamente, das interações de tais expressões com o motivo artístico do "portador do modelo de arquitetura", figuração característica da arte medieval, que apresenta um personagem tendo nas mãos um objeto de tamanho reduzido e formas arquitetônicas, como uma maquete. Sobre estes bens culturais urbanos, a aproximação proposta fundamenta-se na noção de "survival", "nachleben" ou sobrevivência, no entendimento de fenômenos de longa duração profundamente enraízados na memória coletiva, e no conceito de "pathosformeln". Em termos metodológicos esta pesquisa propõe uma aproximação visual e antropológica aos fenômenos mencionados, contextualizando-os e articulando-os ao universo imaginário das representações da arquitetura.

Palavras-chave: Representações. Imaginário. Arquitetura. Modelos Arquitetônicos.

As imagens antigas chegam à nova cultura humanística através da escuridão, da indistinção, da irracionalidade da Idade Média, o que mais uma vez demonstra a sua sobrevivência no profundo e a sua transmissão com o próprio fluxo da existência... É a ordem do fazer que dá ordem às recuperações mnemônicas, ao movimento de imaginação. (ARGAN, 1992, p.51-52)

O motivo artístico do "portador do modelo de arquitetura” é um tema iconográfico arcaico, com expressões no mundo antigo, no Oriente-próximo e nas franjas do Mediterrâneo, e que teve seu apogeu no mundo bizantino (ROZESTRATEN, 2007). Este motivo apresenta

\footnotetext{
* Doutor em Estruturas Ambientais Urbanas junto ao Departamento de História da Arquitetura e Estética do Projeto da Faculdade de Arquitetura e Urbanismo da Universidade de São Paulo (2007), mesma instituição onde desenvolveu seu mestrado (2003) e graduou-se em Arquitetura e Urbanismo (1995). Atualmente é professor na FAUUSP-São Paulo junto ao Departamento de Tecnologia. Tem experiência profissional na área de projeto e gerenciamento de obras atuando como pesquisador nos seguintes temas: iconografia e imaginário da arquitetura, maquetes e modelagem tridimensional, representação do projeto de arquitetura, história do projeto e da tecnologia da arquitetura. Email: artur.rozestraten@usp.br.
} 
um personagem - bispo, papa, príncipe, rei, santo, senhor ou arquiteto - tendo nas mãos um objeto com tamanho reduzido e formas arquitetônicas. O acervo de imagens em mosaicos, relevos e afrescos destes portadores retratados nas paredes de igrejas é reconhecido internacionalmente em seu valor artístico e histórico, e faz parte do patrimônio, da cultura visual, e mesmo da identidade gráfica de inúmeras cidades e vilarejos, da Armênia à França, da Itália à Alemanha.

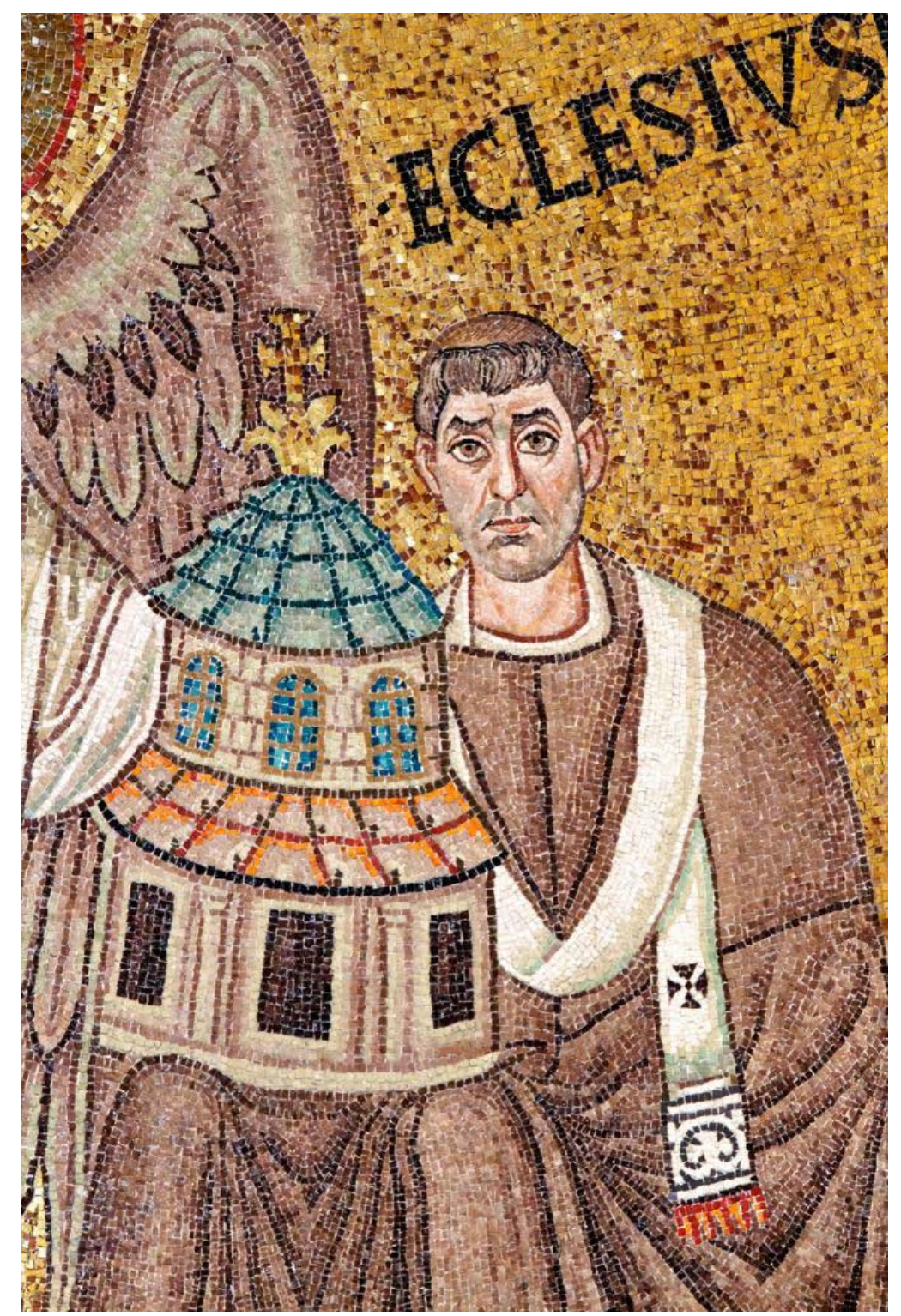

Figura 1: O Bispo Eclesius portando o modelo de arquitetura, em mosaico, na semicúpula da abside da igreja de S. Vitale em Ravena, Itália (546-547). Fotografia de Nick Thompson, com direitos regidos por Creative Commons. Disponível em: <http://www.flickr.com/photos/pelegrino/5222649734/>. Acesso em: 27 fev. 2011. 
Dois ritos populares recolocam em cena nas ruas de duas cidades brasileiras esta antiga figura do "portador do modelo de arquitetura”. Figuração com fundamentos longínquos nas memórias de um catolicismo mestiço, como tradição revivida, performática, moldada nas variadas confluências da cultura brasileira, e constituída nas fusões entre sagrado e profano, arcaísmo e modernidade. Tais expressões contemporâneas, caracterizam-se como patrimônio vivo, ou bens culturais em movimento, como tradições populares cambiantes, em transformação contínua. Sua perpetuação depende antes de tudo de um enraizamento em seu meio - especialmente entre os mais jovens -, que se fortalece com o reconhecimento social de seu valor, de sua natureza e de sua amplitude cultural, que neste caso abarca técnicas, poéticas e aspectos do imaginário popular relacionados ao universo da arquitetura.

Em Belém do Pará tais portadores são os promesseiros do Círio de Nazaré, que carregam seus modelos de casas e igrejas nos braços ou apoiados sobre a cabeça ${ }^{1}$ no meio da multidão, como oferenda votiva em graça à casa construída, ou como pedido da graça da construção de uma casa.

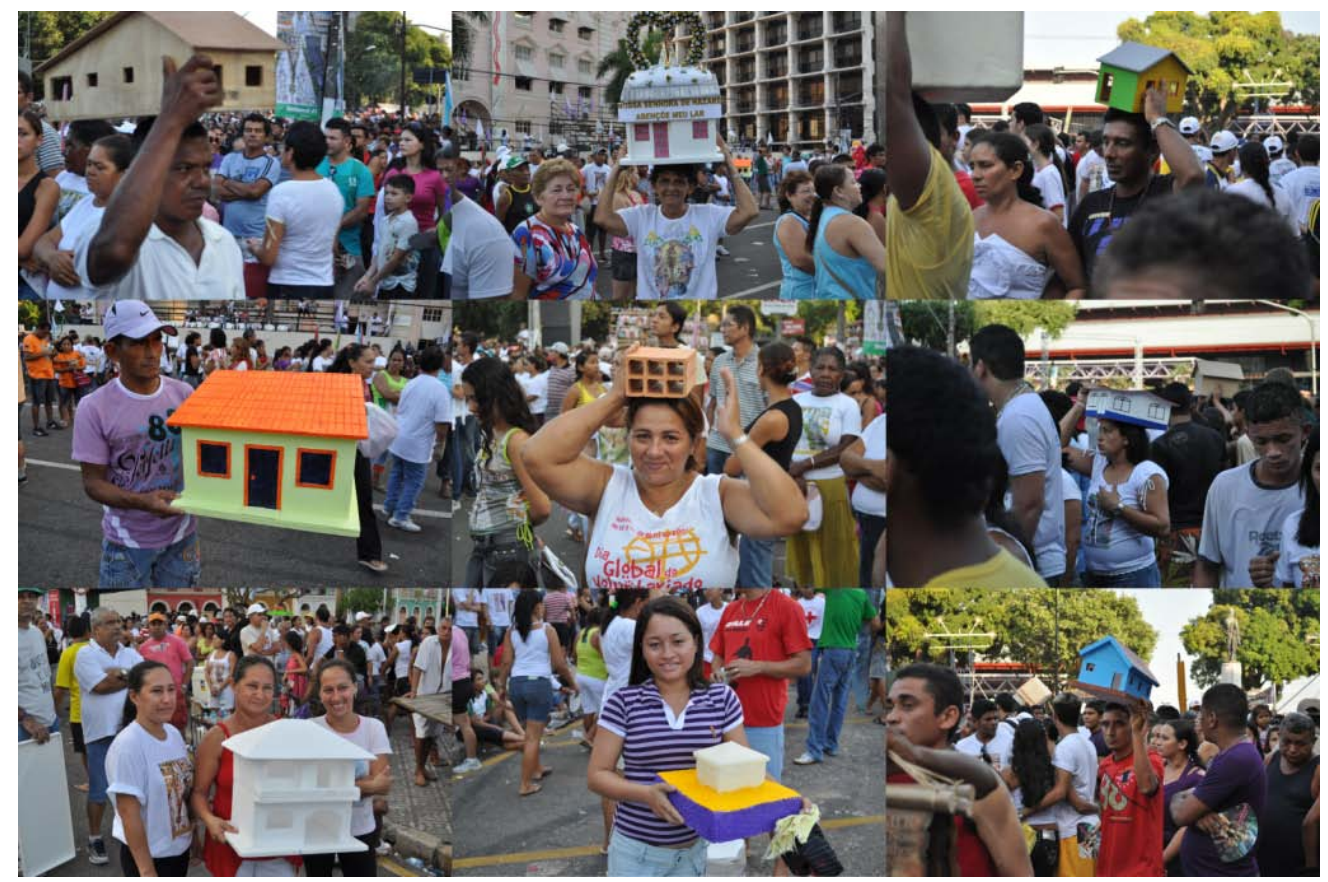

Figura 2: Promesseiros como "portadores do modelo de arquitetura” na procissão da manhã de domingo 10/10/2010, do Círio de Nazaré em Belém do Pará. Fotografias e montagem do autor.

\footnotetext{
${ }^{1}$ A postura de corpo do promesseiro-portador é a mesma de quem carrega um cesto, um jarro, ou uma lata d’água na cabeça, gesto arcaico que sobrevive na cultura indígena, na cultura africana e no norte e nordeste do Brasil. Este gestual não tem expressão na iconografia medieval, uma de suas primeiras e rara figurações é uma imagem composta por Francesco Martini de fins do séc. XV.
} 
Por sua vez, em Maceió e outras cidades alagoanas, os portadores são personagens do Auto do Guerreiro com seus chapéus com formas de “catedrais” com torres. Sobre a cabeça destes "brincantes", transformado em chapéu, o modelo arquitetônico se funde ao corpo ${ }^{2}$, tornando-se sua extensão orgânica e constituindo, assim, um único ser fabuloso: homemtemplo, homem-arquitetura, explorando o campo simbólico das analogias entre o corpo e o edifício.

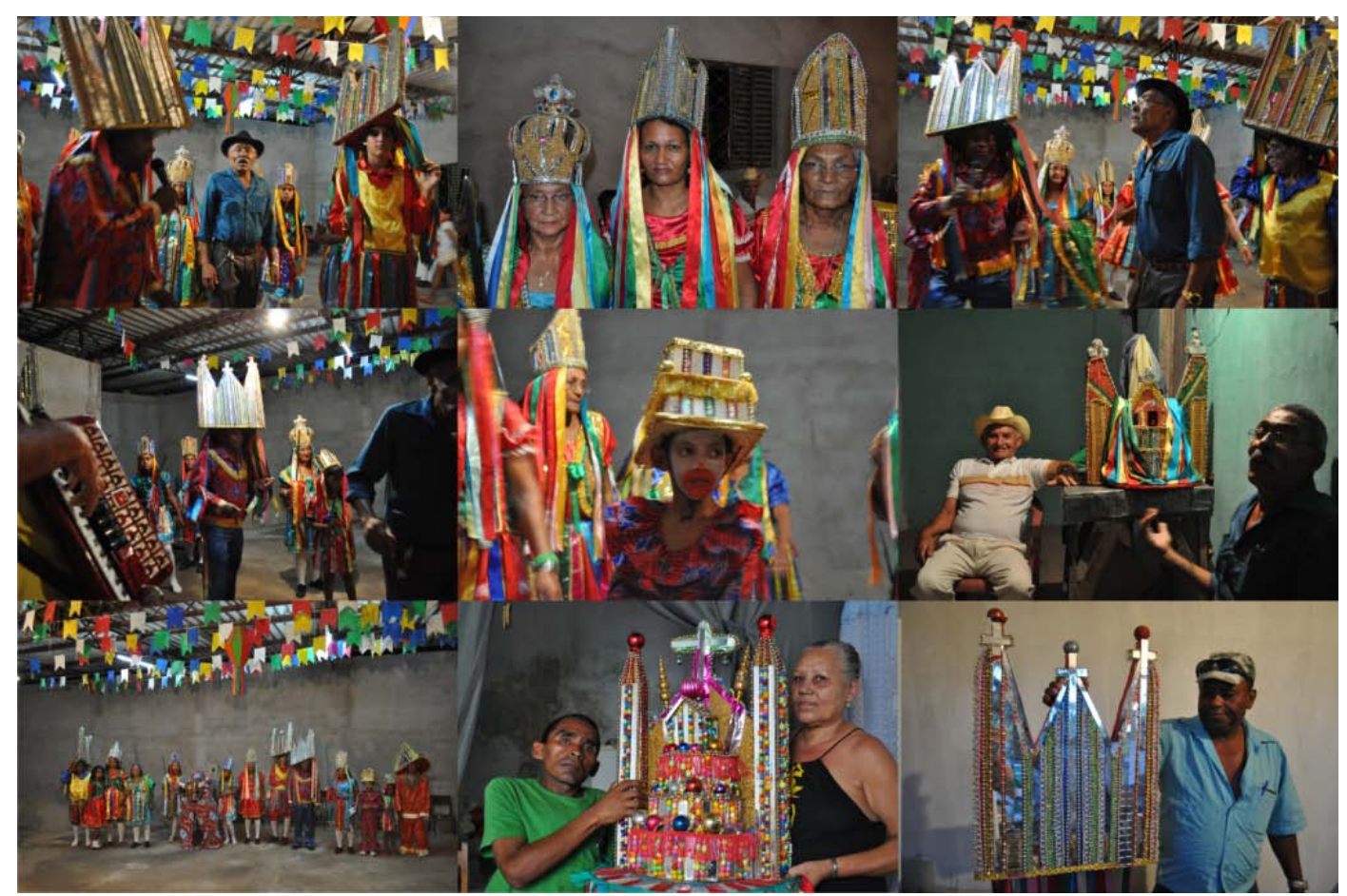

Figura 3: Brincantes do Guerreiro alagoano, dezembro de 2010, Maceió, Alagoas. Fotografias e montagem do autor.

A pathosformeln (WARBURG, 1999) de outrora - composta em poses circunspectas nas paredes das igrejas medievais -, sobrevive nas ruas de Belém e Maceió, em apropriações ecléticas, com rezas, músicas, cantos e danças, que expõem, na gestualidade da interação corporal com os modelos arquitetônicos, e no vínculo com o imaginário da arquitetura, um fenômeno de longa duração (BRAUDEL, 1992), profundamente arraigado na cultura ocidental, e ainda não devidamente estudado.

Os promesseiros de Belém e o Guerreiro alagoano são exemplos vivos do que Edward Burnett Tylor (1873) conceituou como survival, continuidade, pós-vida, Nachleben para Aby Warburg (1999), sobrevivência para Didi-Huberman (2002). No Pará e nas Alagoas,

\footnotetext{
${ }^{2}$ A postura do corpo de quem tem o costume de carregar algo na cabeça permite equilibrar esse objeto sem a ajuda das mãos.
} 
conforma-se o fenômeno de sobrevida de imagens pagãs arcaicas - preservadas e transformadas ao longo do curso do tempo, submergindo e aflorando sempre assemelhadas e distintas de suas antecedências -, apropriadas pelo imaginário cristão medieval, que afloram hoje no Brasil contemporâneo, flertando com suas raízes profanas e sua memória longínqua de ritos votivos. Na formulação de Arthur Ramos (2007, p.230), “... é uma fantasmagoria. Num tempo absolutamente restrito, assistimos à recapitulação de toda uma vida coletiva.”

Esse artigo expõe uma aproximação comparativa entre promesseiros, Guerreiro e o motivo artístico dos "portadores do modelo arquitetônico", no âmbito específico da arquitetura e de seu imaginário, considerando tais expressões como manifestações relacionadas ao entendimento acerca da concepção dos ambientes construídos pelo homem, uma segunda natureza de artifícios: edifícios, cidades e seus espaços urbanos.

A partir dessa introdução, cabem aqui algumas breves considerações para contextualizar o fenômeno dos portadores em Belém e Maceió.

\section{Contextos}

Belém do Pará é uma cidade fluvial, feita às margens do rio Guamá, um dos braços do Amazonas junto à sua foz. Belém está para o Amazonas assim como o Cairo está para o Nilo. É uma cidade portal, que dá acesso ao mundo amazônico, às águas de Santa Maria de la Mar Dulce. Posição estratégica que os portugueses firmaram desde 1616, sob o reinado de Felipe II, com a base militar do Forte do Presépio, núcleo original da cidade, onde se construiu então uma capela dedicada à Nossa Senhora das Graças. Desde o início da colonização, as divindades femininas da tradição mediterrânea transferiram seus vínculos à exuberância úmida da natureza equatorial (SAINTYVES, 1960). Depois dos soldados vieram os franciscanos, em 1618, e em seguida os padres evangelizadores da Companhia de Jesus, que ali permaneceram até 1760, quando, sob a política laica do Marquês de Pombal, foram expulsos e a cidade se firmou como porto exclusivo da Amazônia sob a égide da Companhia Geral do Comércio do Grão-Pará e Maranhão (1755) (FILHO; SEYNAEVE, 1992).

Na segunda metade do séc. XVIII, este antigo sítio dos Tupinambás tornou-se local de residência da elite comercial portuguesa. Consolidou-se como cidade-porto moderna, enriquecida com o comércio da borracha, da castanha, do açaí e da bauxita, sede de desigualdades, terra de contrastes, lugar de conflitos políticos e religiosos históricos, da expulsão dos jesuítas à Cabanagem, do tráfico de drogas à disputa atual de poder entre 
evangélicos e católicos (FILHO; SEYNAEVE, 1992).

Ananindeua, Benevides, Marituba, Santa Bárbara, Santa Isabel e Belém compõem a Região metropolitana da capital paraense, reunindo cerca de dois milhões e cem mil habitantes em 2010, segundo o IBGE.

Tendo sido nomeada, em suas origens coloniais, como Santa Maria do Grão Pará, a capital paraense preservou ao longo de sua história este vínculo com a Virgem, deusa-mãe geradora, hoje "Rainha da Amazônia”. Tal ligação com Nossa Senhora, ritualizou-se na virada do século XVIII para o XIX, com a procissão do Círio de Nazaré, originada do culto à uma imagem movente, com capacidade sobrenatural de se deslocar de um lugar a outro à revelia dos desígnios humanos. O mito de tais deslocamentos da Madona com o menino ao seio definiu as etapas do rito de culto que, desde suas origens, envolve peregrinações, romarias, traslados terrestres e fluviais da imagem. Inicialmente vespertinas e noturnas, estas procissões eram feitas à luz de velas, por isto o nome círio, vela grande de cêra.

As festividades do Círio tem seu ápice no segundo final de semana de outubro, e chegam a reunir mais de dois milhões de pessoas nas ruas de Belém na manhã do domingo. Trata-se de uma multidão maior do que a de muçulmanos que conflui à Meca durante todo o Hajj. Em meio a este mar de devotos, alguns promesseiros portam consigo miniaturas de casas, como modelos ou maquetes, feitos de isopor, ou de miriti, ou ainda de cêra, e há também quem carregue blocos cerâmicos, tijolos, alguns pintados com portas e janelas. Estes são os “portadores do modelo arquitetônico” no contexto paraense do Círio de Nazaré.

Maceió, por outro lado, é uma cidade litorânea, marítima, de praias verdes com barreiras de corais, delineada por coqueirais, e rodeada por lagoas. Capital moderna do estado das Alagoas, região que no início da colonização, em meados do séc. XVI, sediou engenhos de açúcar e comércio de madeira. Terra dos Caetés, indíos antropófagos que devoraram o Bispo Sardinha, e que, por isto mesmo foram dizimados, exterminados pelas tropas portuguesa. Sofreu depois invasões holandesas e, nas brechas de liberdade abertas pelos conflitos entre senhores, abrigou quilombos de negros fugidos, como Ganga Zumba e Zumbi dos Palmares (1655-1695). Alagoas guarda em suas origens conflitos violentos, enfrentamentos entre grupos armados, massacres de índios e lutas de resistência de escravos africanos.

No início do séc. XVIII, Alagoas foi elevada a comarca devido à importância de sua produção de açúcar, fumo, algodão, couro e madeiras. Desmembrada da Vila de Santa Maria Madalena da Lagoa do Sul (atual Marechal Deodoro), Maceió tornou-se capital da província das Alagoas em 1839. 
Inicialmente terra de quilombolas, pescadores, senhores de engenhos, padres, comerciantes e homens de letras, no século XIX, as Alagoas viveram vários conflitos políticos, dentre os quais a Cabanada, nos anos 1830, e a revolta liberal dos "lisos” em 1844. Região de discórdia entre oligarcas e republicanos, que gerou Deodoro da Fonseca (18271892) e Floriano Peixoto (1839-1895), Graciliano Ramos (1892-1953) e Aurélio Buarque de Holanda (1910-1989).

Hoje a região tem sua economia apoiada na exportação de açúcar e etanol, e na atividade turística. O segundo menor estado do país enfrenta ainda a luta contra a corrupção na política, a desigualdade social e a exploração sexual de menores. É em tal contexto que se formou e se perpetua, com dificuldades, o folguedo natalino do Guerreiro, a seguir exposto.

A partir de meados de dezembro, na quinzena que antecede a celebração do Natal, grupos de figurantes trajados brincam o Guerreiro com música, dança e canto, celebrando o reconhecimento mítico do nascimento do filho de Deus. É um folguedo derivado do Congo (RAMOS, 2007), do Reisado e do auto dos Caboclinhos (BRANDÃO, 1976; ROCHA, 1977), com acompanhamento de pandeiro, tambor e acordeão, diversos personagens ou "figuras", que apresentam uma suíte de cantigas ou "peças”, cantadas coletivamente, nas quais cabem “entremeios”, ou pequenas partes inseridas nas peças, e o trupé, a batida ritmada dos pés no tablado ou no chão. Como no Reisado, tradicionalmente os Guerreiros cantam os Pedidos de Abrição de Porta ou de Sede, as peças de Entrada de Sala ou de Sede, a Louvação ao Divino, as Marchas de Ruas e outras peças “amorosas”, “de elogio”, “de época”, “do boi”, além de suas partes típicas, exclusivas, como a da Estrela de Ouro, da Estrela do Norte, da Sereia, do Índio Peri e da Lira. Ao final, o grupo canta sua saída, retirada ou despedida (BRANDÃO, 1976). Ao longo desta sequência dramática, há lutas de espadas, algumas figuras morrem e ressuscitam, como é característico dos mitos de "sobrevivência” simbólica que marcam passagens como o início de uma estação ou um novo ano (RAMOS, 1951), inaugurando assim, ritualisticamente, um novo espaço e um novo tempo entrelaçados e consagrados.

Entre 1943 e 1945, o fotógrafo francês Michel Gautherot (1910-1996) fotografou o Guerreiro Alagoano (PERALTA, 2007), em vigorosas imagens em preto e branco, que registraram a expressividade emocional dos corpos, seu gestual, e sua indumentária em movimento, assim como a exuberância de seus monumentais chapéus arquitetônicos. Estas imagens do folguedo alagoano expuseram ao Brasil e ao Mundo - no pavilhão brasileiro na Exposição Universal de Bruxelas em 1958 (SEGALA, 2005) -, a vitalidade de uma expressão artística na qual se evidenciava visualmente a sobrevivência de formas arcaicas, ibéricas, africanas e bizantinas, no mundo moderno. 
Antes de empreender uma descrição mais detalhadas dos "portadores do modelo arquitetônico" no contexto paraense e alagoano, cabem algumas considerações sobre o histórico de estudos e o estado da arte quanto ao tema.

\section{Breve histórico do estudo dos promesseiros}

Em 2006, o IPHAN publicou um dossiê sobre o Círio de Nazaré com o propósito de registrar e inventariar tal fenômeno. Essa publicação apresenta aspectos históricos, descreve as várias etapas da festa, evidencia suas ambiguidades entre o caráter profano e religioso, apresenta mapas dos vários percursos já realizados pela procissão, e traz uma organização importante das referências bibliográficas existentes sobre o assunto. Ainda que o referido trabalho apresente várias qualidades, percebe-se, contudo, a ausência de um reconhecimento da expressão singular dos promesseiros e suas arquiteturas portáteis.

O estudo do Círio é recente, muito embora alguns estudos pontuais tenham sido feitos ainda nas primeiras décadas do século XX, como o de Artur Vianna de 1904, e o de Manuel Barata de 1921. Pode-se dizer que a produção sistemática de estudos sobre o tema se organiza apenas a partir de fins da década de 1960.

O estudo do geógrafo Eidorfe Moreira, de 1971, inaugura o enfoque das ciências sociais sobre o fenômeno do Círio, e explora as interações territoriais, políticas e sociais. Na década seguinte, o jornalista Carlos Rocque compôs uma relevante síntese sobre a história da festa, publicada em 1981, como desdobramento de um tema específico dentro de seu projeto “Grande Enciclopédia da Amazônia”, que fora publicado em 1968. Registra-se também que, desde os anos 1970, Rocque se dedicara ao estudo do Círio, tendo publicado em 1974 no jornal “A Província do Pará”, um caderno especial com uma aproximação preliminar à história desta festividade.

Os jornais e revistas, aliás, continuam cumprindo um papel importante na organização e difusão de informações acerca do Círio, como fazem hoje os telejornais e os principais veículos de imprensa escrita de Belém, como o Diário do Pará, O Liberal, e O Paraense. A importância desse vínculo, e das interações entre a imprensa e o Círio, foram estudadas por Heraldo Montarroyos no início dos anos 1990.

Voltando aos anos 1980, duas publicações merecem menção: a primeira é o estudo de Isidoro Alves (1980) que explora as analogias e conflitos entre o caráter sacro e laico do Círio; a segunda é o livro de Mízar Klautau Bonna (1986), que enfatiza e documenta os 
aspectos religiosos da festa.

A partir de meados dos anos 1990, os estudos do antropólogo Raymundo Heraldo Maués (1995, 1999, 2000), professor emérito da UFPA, centraram-se em análises das festividades consagradas à Virgem de Nazaré, sob o prisma da antropologia das religiões, dos mitos e do imaginário.

Valorizando os enfoques antropológicos e teológicos, com diferentes abordagens que evidenciam a multiplicidade de aproximações possíveis ao tema, há que se fazer referência também à publicação “Círios de Nazaré”, organizada por Josimar Azevedo em 2000.

Cabe mencionar ainda, a publicação de 2001, “Cultura Amazônica: uma cultura do imaginário”, na qual estão reunidos os estudos de João de Jesus Paes Loureiro sobre os grandes Círios fluviais da região - a saber, o Círio de Nossa Senhora de Nazaré de Belém, o de Nossa Senhora de Santana em Óbidos, e o de Santo Antônio em Oriximiná -, assim como suas análises sobre a produção artesanal de modelos em miriti, os chamados "brinquedos de miriti”, fabricados com a madeira da palmeira de mesmo nome, na época do Círio, especificamente no município de Abaetetuba, localizado à cerca de $60 \mathrm{Km}$ da capital paraense.

Em 2005, o Professor Sílvio Figueiredo, da UFPA, organizou a publicação intitulada “Círio de Nazaré: festa e paixão”, onde a sobreposição de aspectos profanos e sagrados da festa são analisados sob perspectivas que salientam questões políticas, comerciais, organizacionais, turísticas e simbólicas. Nos últimos cinco anos, algumas pesquisas acadêmicas dedicaram-se ao tema, como é o caso da dissertação de mestrado de Vanda Pantoja (2006) que estuda as interações entre mercado e igreja, e da tese de doutorado de Josimar Azevedo (2008), concentrada sobre a questão teológica da fé.

Todos estes estudos colaboram para a pesquisa em curso. Contudo, até o momento, não há estudos específicos sobre a representação da arquitetura nos objetos votivos, tampouco sobre as relações com o gestual e a performance dos promesseiros e seus vínculos com a iconografia do "portador do modelo arquitetônico”, que constituem o enfoque deste trabalho. O estudo em andamento, que aqui se apresenta, pretende construir uma aproximação concentrada sobre o fenômeno dos promesseiros que portam modelos com formas arquitetônicas miniaturizadas, investigando as interações históricas desta prática com ritos e expressões artísticas anteriores, assim como suas relações com a arquitetura real e, consequentemente, com o imaginário, entendido aqui como o campo de entrelaçamento de ideias e formas plásticas acerca da concepção, contrução e permanência das arquiteturas no cotidiano. 


\section{Breve histórico do estudo do guerreiro}

Conforme Abelardo Duarte (1975), a primeira menção ao Guerreiro alagoano teria sido feita por Arthur Ramos (1903-1949), em seu livro "Folk-lore Negro do Brasil: demopsicologia e psicanálise”, editado no Rio de Janeiro pela Casa do Estudante do Brasil, em 1935. Tal registro, em meados dos anos 30, referencia inclusive a datação do surgimento deste folguedo, já que não há conhecimento, até o momento, de nenhuma menção na imprensa escrita ou na bibliografia pertinente anterior à meados dos anos 1930.

Ramos (2007) inicia sua aproximação ao autos populares que conduzem ao Guerreiro, sob a noção de "survival”, derivada de Tylor (1873). Para Ramos, os jesuítas já haviam adaptado na catequese "autos de sobrevivência medieval”, e assim também o fizeram os negros com os autos "peninsulares”, “mouriscos e cavalheirescos”, trazidos pelos colonizadores europeus para o Brasil. A esta vertente ibérica, adaptada à colônia, os africanos acrescentaram seus Congos, encenação dramática de "antigas lutas das monarquias e reinos africanos entre si e contra o colono invasor" (p.30) e "sobrevivências da coroação de monarcas africanos nas terras de origem” (p.32). Nada mais próximo à experiência histórica dos quilombolas nas Alagoas. O enredo de saudação, lutas, morte e ressureição, as “dramatis personae” do Rei ou “Emperadô", da Rainha, do Embaixador, das princesas e guerreiros, caracterizam o Congo no Nordeste brasileiro, do início do séc. XVIII, como uma das principais fontes do moderno Guerreiro Alagoano. A tais elementos o sincretismo somou outros mais, como o urso, o lobisomem, a sereia, a borboleta, o zabelê e as "coroas de papelão cobertas de papel pintado e dourado” (PEREIRA DA COSTA apud RAMOS, 2007, p.72), transformadas em chapéus de "catedrais”.

Dentre todos os estudos já realizados sobre o Guerreiro, o primeiro, de Arthur Ramos é o que aí identifica mais categoricamente os indícios de sobrevivência de folguedos africanos que “entremostraram-se assim disfarçados e irreconhecíveis” (p. 229). Nos estudos subsequentes, mesmo de seus seguidores mais próximos, as origens africana são minimizadas, para não dizer ignoradas ${ }^{3}$. É curioso notar que Ramos descreve o auto dos "guerreiros", apresenta seus personagens e o enredo da "luta entre dois partidos" (RAMOS, 2007, p.91), mas não faz nenhuma menção aos chapéus em forma de igreja, que adquirem, assim, uma história enigmática, um registro pela ausência.

\footnotetext{
${ }^{3}$ Mário de Andrade (1893-1945) (apud RAMOS, 2007) no artigo Os congos, Boletim da Sociedade Filipe d’Oliveira, fev. 1935, p.38, é um dos raros autores contemporâneos a Ramos que enfatizam e valorizam esta presença da cultura negra na formação da cultura e do imaginário brasileiros. Esta mesma exceção também deve ser feita a Roger Bastide (1898-1974).
} 
Théo Brandão (1907-1981), - que já mencionara o Guerreiro em seus estudos sobre “O Reisado Alagoano” de 1951 e sobre os “Folguedos Natalinos” (1961) -, veio a escrever a primeira monografia sobre o tema (1964), e relata não se lembrar de ter visto o Guerreiro antes da década de 30 (apud DUARTE, 1975).

Menciona-se também que o Guerreiro teria surgido no interior de Alagoas, em Viçosa, entre 1927 e 1929. Em meio às divergências quanto à datação das origens - que também se associam ao bairro de Bebedouro em Maceió -, o que é fato é que Ramos e Brandão foram pioneiros no estudo do tema, identificaram, descreveram e valorizaram o auto natalino do Guerreiro, merecendo por este trabalho menção de Câmara Cascudo (1898-1986), em seu Dicionário do Folclore Brasileiro, de 1954, no qual o autor registra seu próprio encantamento com os “chapéus maravilhosos, imitando catedrais” (p. 441).

O problema ou enigma das origens do Guerreiro é singular, pois trata-se de um folguedo moderno, recente, engendrado em pleno século XX, dentro de um contexto urbano, e mesmo assim, surpreendentemente envolto em imprecisões e dúvidas. Contudo, em termos metodológicos, o exame das origens no sentido geográfico-espacial e cronológico-histórico não deve se filiar à "crença estreita num ponto ou foco inicial de origem [...] mas se considerarmos um foco provável de disseminação inicial para acompanhar as transformações posteriores pela difusão, veremos que são fecundos muitos de seus resultados” (RAMOS, 1951, p.93). Tais considerações sugerem que o estudo das origens do Guerreiro amplie sua abrangência, considerando em seu escopo, o estudo da difusão do folguedo, a descrição atual do auto e de seus possíveis desdobramentos, assim como estudos aprofundados sobre o contexto alagoano nas primeiras décadas do século XX.

Há que se registrar aqui também, nesta revisão de estudos sobre o tema, a visão panorâmica, sintética e densa de José Maria Tenório Rocha (1977), discípulo de Théo Brandão, a respeito das interações do Guerreiro com o Folclore Alagoano, e as menções ao auto do Guerreiro, feitas no estudo de Tânia de Maya Pedrosa (2000).

Duas outras iniciativas recentes devem ser citadas aqui, por contribuirem significativamente com os estudos sobre o assunto: a primeira é o livreto e os CDs intitulados “A parte do Índio Peri do Guerreiro” recolhido e transcrito por Gustavo Quintella (2000). Belíssimo trabalho de grande qualidade artística e documental; a segunda é a iniciativa da ASFOPAL - Associação dos Folguedos Populares de Alagoas, que lançou recentemente um registro de seus 25 anos de trabalho, com biografias e fotografias dos principais mestres da cultura popular alagoana (2010), dentre os quais vários mestres de Guerreiro.

Quanto à iconografia, as já mencionadas fotografias de Gautherot feitas em Alagoas 
no início dos anos 40 (c. 1943), por solicitação do SPHAN - Serviço do Patrimônio Histórico e Artístico Nacional, inauguram um corpus documental etnográfico, revelador de uma postura metodológica, que almejava a objetividade científica do registro descritivo, patrimonial, valendo-se, contudo, da subjetividade e da composição artística do fotógrafo para tanto (SEGALA, 2005).

Outro conjunto significativo de imagens são as fotografias coloridas feitas pela antropóloga e folclorista norte-americana Katarina Real (1927-2006), em Maceió, no início dos anos 1960, que além de acrescentarem cor à documentação etnográfica do Guerreiro expondo a policromia e os contrastes nas estampas e nos chapéus -, reforçaram as possibilidades de múltiplos olhares sobre o fenômeno, e a necessidade de estudos acadêmicos sistemáticos a respeito. Atualmente, este acervo fotográfico está sob a guarda da Fundação Joaquim Nabuco, em Recife.

Delineado o histório de estudos já realizados, e expostos os desafios desta pesquisa, segue-se, então, a seguir, a descrição contextualizada dos portadores e de seus modelos no Círio e no Auto do Guerreiro.

\section{Promesseiros de Belém do Pará}

Na procissão da manhã do segundo domingo de outubro, em meio à multidão, alguns promesseiros destacam-se por levarem consigo uma casa em miniatura, nos braços, quando há espaço, ou apoiada sobre a cabeça, quando não há. Tal gestual os caracteriza como sobreviventes da condição de "portadores do modelo arquitetônico", e os relaciona a toda a amplitude simbólica da casa e, por decorrência, do habitar, do imaginar e do construir.

Os "modelos reduzidos", que constituem o tipo ou protótipo da obra de arte (LÉVISTRAUSS, 1962, p.37), no contexto do Círio de Belém, podem ser caracterizados como oferendas, ex-votos, isto é, objetos ofertados com intenção votiva, por uma graça alcançada ou a alcançar, e são bastante variados em tamanho, forma, cor, material e fatura. A grande maioria destes modelos é feita pelo próprio portador-promesseiro e, conforme os depoimentos colhidos, assemelhar-se-ia à casa já construída, ou àquela que se deseja construir. Essa “concepção” pessoal ou coletiva-familiar do objeto, amplia a experiência estética ativa para além da mera contemplação do objeto pronto, e inclui a fatura como processo que permite ultrapassar a simples representação - o homólogo passivo, no dizer de Lévi-Strauss (1962, p.38) - em favor da constituição de uma originalidade artificial. 
Contudo, há também aqueles que optam pela compra de um objeto artesanal pronto, como os ditos "brinquedos” de Miriti, em formato de casa. Há ainda a opção de comprar com ambulantes, um modelo genérico de casa, industrializado, feito em parafina sem pigmentação, a partir de um molde.

Os materiais predominantes utilizados na confecção dos modelos arquitetônicos do Círio de Belém são: o miriti - madeira muito leve e macia, conhecido como o "isopor da Amazônia”, retirada do talo da palmeira Buriti ou Miritizeiro -; o isopor (poliestireno expandido); e madeiras maciças ou em chapas variadas. Tais materiais, são geralmente coloridos, e compõem objetos minuciosamente detalhados, com analogias a elementos arquitetônicos como telhas, cumeeiras, beirais e caixilhos. Há também variações mais simples, monocromáticas, e mesmo objetos despojados com o material "natural” sem pigmentação. Além dos materiais mencionados, utilizam-se ainda alternativas “de ocasião”, como: papelão de caixa, placas de forro de pvc, e outras chapas plásticas.

Alguns promesseiros, ao invés de portarem o modelo de uma casa, levam um bloco cerâmico, ou um tijolo maciço. A opção por materiais de construção ao invés de “maquetes”, associa-se, geralmente, à condição da oferenda votiva pela conclusão da obra, ou como “pedra fundamental”, bauopfer (oferenda de fundação) (ELIADE, 1992, p. 53), em graça pela aquisição do terreno e início dos trabalhos.

Quanto à volumetria, há desde modelos muito esquemáticos, prismáticos, até objetos mais detalhados, que evidenciam um telhado com beirais, com cobertura em uma água, em duas águas - que é o mais comum - e, com cobertura em quatro águas. Além destes tipos, há também variações volumétricas mais raras, com vários telhados, sacadas, terraços e mesmo chaminés.

Há que se mencionar ainda, modelos excepcionais, que representam igrejas, assemelhadas a arquiteturas reais, com nave e torres, ou mesmo fantasiosas, seja como catedrais, seja como capelas muito simples, ou ainda como “naískos”, isto é, um pequeno templo estilizado com grande liberdade formal.

É comum os modelos estarem fixos a uma base mais larga que seu corpo principal, conformando um "terreno" de apoio, e apresentarem elementos arquitetônicos, como portas e janelas. Tais aberturas ou vãos, em alguns casos, chegam a expor o espaço interno do objeto. Nesse espaço, alguns promesseiros depositam pequenas oferendas: pedaços de ladrilhos, bilhetes à Santa, santinhos com orações, etc. 


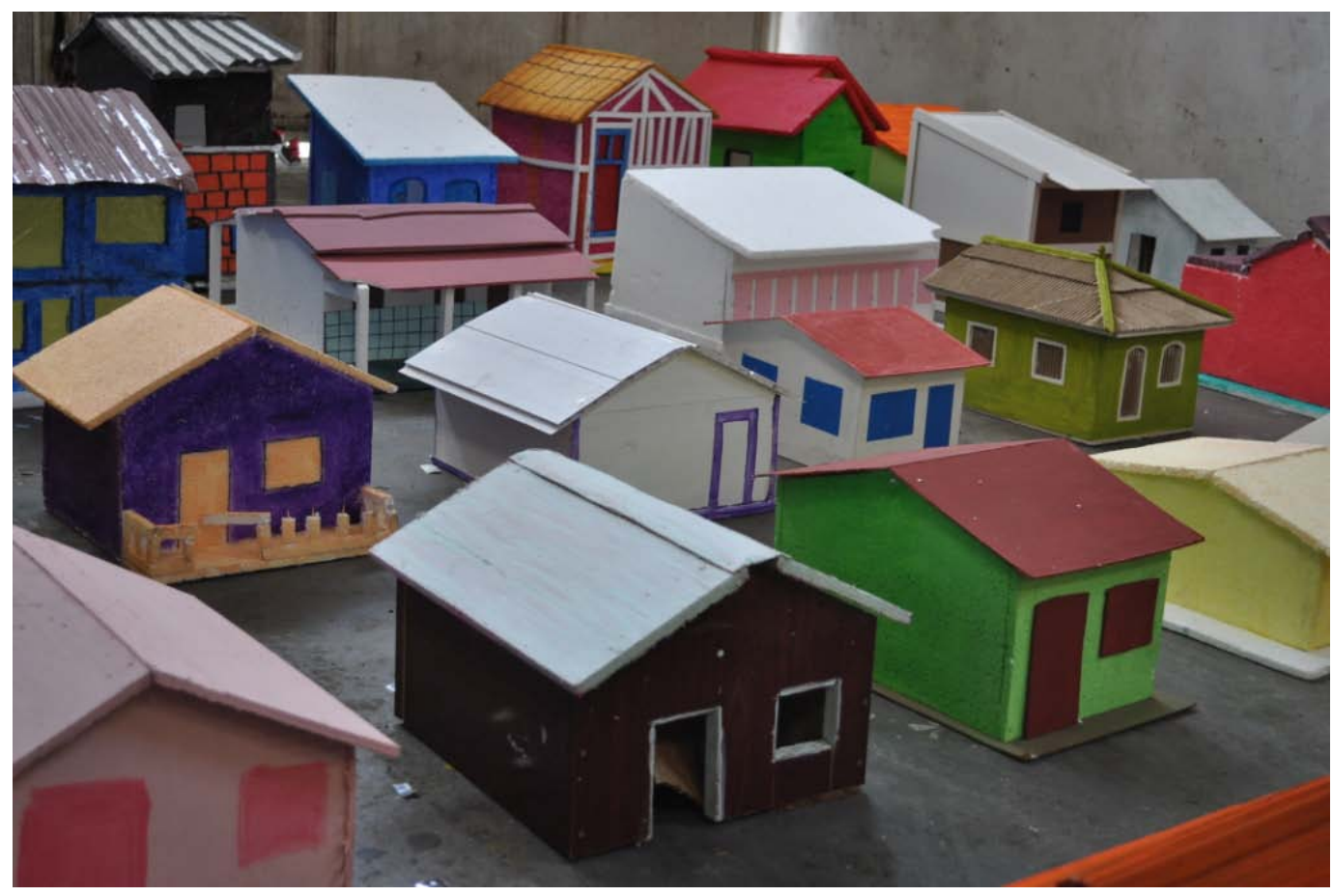

Figura 4: Conjunto de modelos arquitetônicos levados em oferenda pelos promesseiros na procissão da manhã de domingo, 10/10/2010, do Círio de Nazaré, em Belém do Pará, dispostos no piso do Galpão de oferendas compondo uma cidade imaginária. Fotografias e montagem do autor.

Ao longo da procissão, os modelos arquitetônicos são depositados junto a velas e outros ex-votos nos carros de recolhimento de promessas, carros de oferendas, ou carro “dos milagres”, com suas estruturas estilizadas em forma de barcos. Encerrado o circuito do rito, estes carros são conduzidos a um galpão próximo à basílica de Nossa Senhora de Nazaré, onde alguns peças são selecionadas - por sua qualidade plástica, originalidade e singularidade -, e passam a integrar o acervo do Museu do Círio. Ao final das festividades, todas as demais oferendas são cremadas em cerimônia conduzida pelo bispo de Belém, quando então desmaterializam-se as arquiteturas.

\section{Guerreiros alagoanos}

A partir de meados de dezembro, os “brincantes” do Guerreiro alagoano saem de suas sedes e se apresentam publicamente até o período do Natal. Originalmente formados por cerca de 80 pessoas, com base familiar, estes grupos se deslocavam entre cidades, vilas, sedes de engenhos e casas de fazenda, realizando uma perfomance de dança e canto remunerada que 
podia levar praticamente toda a noite entre os pedidos de Abrição de Porta ou de Sede, a Louvação do Divino, os vários avisos, peças, entremeios e embaixadas, até a despedida e a retirada da "troupe” (BRANDÃO, 1976).

Atualmente, os grupos são bem menores, com cerca de 20 a 40 figurantes, e as bases familiares se preservam, mas sem ortodoxia. Vários grupos mantêm uma núcleo reduzido permanente e, no caso de agendamento de uma apresentação remunerada, convocam participantes ocasionais, figurantes e músicos, eventualmente de outros grupos. O tempo das apresentações, inseridas dentro de atividades culturais e de entretenimento promovidas pelo município ou pelo estado, é pequeno, no máximo de duas horas e, quando associado a outros folguedos e grupos musicais, esse tempo chega a ser reduzido a apenas meia hora. Os formatos reduzidos descaracterizam o auto, e não são financeiramente viáveis para os grupos, que precisam cobrir seus custos de indumentária, deslocamento e alimentação.

Nos dias de hoje, raros grupos, como o Campeão do Trenado do mestre Nivaldo Abdias, deixam suas sedes - no caso, no Alto da Boa vista, na Chã da Jaqueira em Maceió -, e enfrentam os penosos deslocamentos pelo interior para se apresentarem, e ganharem algum dinheiro pago por prefeitos, vereadores, padres, fazendeiros e particulares.

O folguedo do Guerreiro é hoje cultivado por cerca de 80 grupos sediados em Maceió, Cajueiro, Atalaia, Coruripe, Murici, União dos Palmares, Lagoa da Canoa, Palmeira dos Índios, Arapiraca, Messias, Viçosa e Piaçabuçu. Em Maceió, organizam-se junto à ASFOPAL - Associação dos Folguedos Populares de Alagoas, que reune também outras expressões folclóricas como o Fandango, Caboclinhos, Reisado, grupos de Côco e Forró.

Todo o "figurá" do Guerreiro se traja com roupas coloridas, e quase todos portam espadas, as mulheres usam meias, saias com fitas e coroas com miçangas, lantejoulas, espelhos e fitas pendentes, enquanto os homens usam calça, camisa de manga comprida e colete, também ornamentado, para completar o traje, chapéus altos com fitas presas na base, que caem sobre os ombros nas costas.

Trajados, todos os que brincam o Guerreiro rompem a rotina do cotidiano e transformam-se, embelezam-se, e tornando-se os mais bonitos do mundo, distinguem-se, ganham evidência, são admirados, desejados e invejados. Por isso, os espelhos nos chapéus tem dupla função, pois além de brilhar, servem para refletir a inveja alheia.

O mestre, que é a figura principal e coordena o grupo com seu apito, o contra-mestre, e o palhaço, usam chapéus com formas arquitetônicas. No caso do mestre e do contra-mestre, estes chapéus são “catedrais”, igrejas com torres, feitas de papelão, madeira, espuma e revestidos com tecido coberto de lantejoulas, contas, miçangas, cacos de espelho e bolas de 
árvore de natal, enfim, toda sorte de material industrializado colorido e brilhante. No caso do palhaço, “um capacete especial coberto de espelhos, à moda de uma casa” (BRANDÃO, 2007, p.22), ou com variações em forma de pirâmide escalonada, que se assemelham a “miniaturas de templos do Cambodge” (BRANDÃO, 2007, p.27).

Estes chapéus com formas arquitetônicas, assim como as coroas e diademas, são fabricados artesanalmente por pessoas ligadas aos grupos que preservam uma tradição figurativa, na qual há liberdade para a invenção e a inserção de novos materiais e elementos formais.

Cícero Abdias, conhecido como Cicinho do Campeão do Trenado, é um destes artesãos que confeccionam “catedrais”. Mestre Benon do Guerreiro Treme Terra também constrói chapéus para o seu grupo, atende encomendas e os vende para turistas em sua oficina junto à sede. Mestre André do Guerreiro Mensageiro do Padre Cícero, também confecciona e reforma chapéus e coroas de Guerreiro no fundo de sua casa, no bairro do Tabuleiro, em Maceió.

Os materiais utilizados para a confeção dos chapéus, são cartões de alta gramatura, papelão e espumas densas para a estrutura, tecido e papel metalizado para o revestimento, e para a ornamentação, cacos de espelho, cacos e bolas de natal inteiras, micanças de tamanhos variados, contas, cordões, purpurina, lantejoulas, canutilhos, vidrilhos, strass e fitas vermelhas (encarnadas), verdes escuras, azuis claras e escuras, brancas, cor de rosa, alaranjadas e amarelas, que são colados ou costurados sobre a estrutura revestida. Cor e brilho são qualidades indispensáveis para os materiais utilizados na confeção dos chapéus e, em meio aos artesãos, há abertura para a experimentação de toda sorte de material industrializado, artificial, nacional e importado, disponível no mercado.

Quanto à forma, as “catedrais” dos mestres e contra-mestre, geralmente, possuem duas partes conjugadas: uma fachada tripartida com frontão triangular ao centro, sustentando um cruzeiro e torres de base quadrada nas duas laterais e, atrás deste plano frontal, um volume escalonado de base semi-circular, no qual se encaixa a cabeça. Sobre este volume, geralmente há um pequeno modelo arquitetônico, muito esquemático, com planta retangular e cobertura em duas águas, como uma casa, oratório ou templete, encimado por uma esfera, uma estrela ou uma cruz.

Tal volumetria, com um plano frontal e um volume escalonado atrás, se repete também em alguns chapéus “diademas” das Estrelas de Ouro, de Prata e Brilhante, e mesmo na cajuringa, ou cafuringa, que é o chapelão dos Mateus. Também nestes chapéus, diademas e coroas, é comum encontrar na parte posterior o mesmo pequeno modelo arquitetônico, em 
alguns casos tão sintético que se constitui simplesmente por dois planos inclinados como águas de um telhado. Já no caso dos chapéus dos palhaços, não há plano frontal, nem fitas pendentes, apenas um volume escalonado, geralmente de base quadrada.

As duas partes que compõe as “catedrais” também remetem ao desenvolvimento histórico das igrejas no Brasil colonial, a partir de uma configuração inicial com nave única de planta retangular e frontão triangular que vem a receber depois, a partir do século XVII, o acréscimo de uma fachada ornamentada - que é nitidamente um aplique a reproduzir o frontão triagular, ainda que em alguns casos com volutas -, eventualmente acrescida de torres sineiras.

O mesmo processo de agregação posterior de um plano como fachada cenográfica, fantasiosa, repercute também na arquitetura civil. Em todo o Nordeste do Brasil, é comum a construção de uma fachada ornamentada sobre a despojada fachada original, geralmente ocultando o telhado com platibanda. Este acréscimo, característico das transformações na arquitetura urbano do Brasil do início do séc. XIX, repercute na cidade como um sinal público de prosperidade, destaca o edifício de seus vizinhos alinhados, e contribui para “embelezar” a praça, a rua e a cidade.

Mesmo considerando os aspectos práticos da separação do chapéu em duas partes com um espaço indispensável para encaixar a cabeça -, intui-se na modelagem dos chapéus e “catedrais” a ressonância do processo de desenvolvimento das fachadas de igrejas e residências alagoanas. Evidenciam-se assim, os vínculos entre a arquitetura real e a arquitetura imaginária, que os "brincantes portam sobre suas cabeças no auto-natalino do Guerreiro.

\section{Aproximações interpretativas}

A confluência dos antigos costumes da procissão e da oferenda de objetos com formas arquitetônicas miniaturizadas (LIPSMEYER, 1981; ROZESTRATEN, 2007), característicos das civilizações do entorno da Bacia do Mediterrâneo, conformou o motivo artístico do "portador do modelo de arquitetura”. Suas origens, provavelmente, relacionam-se:

- ao bauopfer, ou ritos de oferendas de construção ou fundação nas culturas neolíticas do sudeste europeu junto ao vale do Danúbio (c.5.800 a 3.500 a.C.), valendo-se de objetos cerâmicos com formas arquitetônicas estilizadas em escala reduzida (ROZESTRATEN, 2003); 
- à tradição próximo-oriental do cortejo, representada no relevo do vaso Warka (peça em alabastro encontrada no complexo do templo da deusa suméria Inanna, depois chamada Ishtar, nas ruínas da cidade de Uruk, datado entre 3200 e 3000 a.C.), nos relevos da escadaria de Apadana em Persépolis (c. 520 a.C.), e, especialmente, no relevo do tributário de Khorsabad (742-705 a.C.);

- ao costume egípcio da procissão de oferendas, que se conjuga ao uso de modelos em escala reduzida, como nos ritos funerários (Toley, 1995), e também nos ritos de fundação, como é o caso do modelo do Rei Sety I (c. 1290 a.C.) (BADAWY, 1972);

- às práticas de oferendas de naískoi em terracota (especialmente nos templos dedicados a Hera, na Grécia, entre o séc. VIII e o VI a.C.) (ROZESTRATEN, 2003);

- à assimilação e difusão do costume próximo-oriental da procissão no mundo grego, expresso nas Panateneias e representado em relevo no friso do Parthenon na Acrópole em Atenas (séc. V a.C.) (ThesCRA, 2004).

No mundo romano tais costumes se desdobraram:

- no uso de maquetes de estudo nos processos de projeto de edificações - como atesta o modelo de Niha (séc. II) (WILL, 1984; KALAYAN, 1971);

- na iconografia da deusa da fortuna Tychè (LIPSMEYER, 1981);

- na "pompa triumphalis";

- na iconografia cristã dos Reis Magos a partir do séc. III (afresco na catacumba de S.Priscilla em Roma).

No mundo medieval, o motivo artístico do portador conformou uma figuração que se manteve bastante coesa em mosaicos, afrescos e relevos até o séc. XII, quando então desdobrou-se novamente (ROZESTRATEN, 2007):

- na alegoria de santos, especialmente S. Bárbara e S. Jerônimo;

- na ornamentação de jacentes, como o de Henrique, o Leão, duque da Saxônia e da Baviera (c.1220) em seu túmulo em Brunswick;

- e na caracterização de arquitetos, como é o caso de Hugues Libergier e do arquiteto da catedral de Ulm que, em um relevo, literalmente sustenta a catedral nas costas. 
Até o momento, as particularidades dos promesseiros do Círio foram tratadas como expressões folclóricas, no âmbito das festividades católicas dedicadas à Virgem, com ênfase nos aspectos religiosos e históricos locais. Quanto ao Guerreiro alagoano, seus vínculos histórico remetem ao imaginário guerreiro de reis e rainhas dos congos africanos, ao culto ibérico dos reis magos (Reisados, Folias de Reis, Santos Reis), à valorização franciscana das celebrações natalinas e suas cenografias de presépios, e à difusão do imaginário de romances de cavalaria e seus guerreiros virtuosos na catequese jesuítica e na literatura de cordel, como o texto “A Batalha de Oliveiros com Ferrabrás” (1913), de Leandro Gomes de Barros (18681918) (BARROS, 2010).

Contudo, os entrelaçamentos de promesseiros e "brincantes" do Guerreiro com o universo da arquitetura ainda não foram evidenciados. Muito embora estes vínculos se façam nítidos na sobrevivência de formas plásticas e gestual relativos aos “naískoi” dos promesseiros e aos chapéus de "catedrais" dos mestres e contra-mestres alagoanos. A visualidade evidencia os vínculos de tais manifestações com o motivo artístico do "portador do modelo arquitetônico", sugerindo interações mais profundas com ritos pagãos arcaicos, desdobrados no imaginário medieval acerca da concepção da arquitetura, identificando permanências, reinvenções e singularidades no contexto da procissão dedicada à Virgem, e do auto natalino, indiretamente também dedicado à Virgem.

Versos compilados por Arthur Ramos em 1935, evidenciam esta celebração à Deusa da concepção no contexto natalino:

"Eu sou a Estrela-de-ouro / Com prazer e consolação / Quero sabê se aqui festeja / A Virge da Conceição. Eu sou a Estrela-de-ouro / Com prazer e alegria / Quero sabê se aqui festeja / Jesus, filho de Maria.” (2007, p.94)

Os costumes de procissão e oferendas a divindades femininas geradoras, e seus desdobramentos iconográficos parecem estar na memória mais profunda das práticas, do gestual e das formas arquitetônicas comuns aos promesseiros e ao Guerreiro.

A “Grande Deusa”, divindade feminina associada à fertilidade, à energia vital e ao poder gerador, e destruidor, da natureza, formou-se plasticamente nas culturas neolíticas do sudeste europeu, e ganhou expressão plástica em estatuetas como a Vênus de Hohle Fels, e de Willendorf. Na Ásia Menor, Anatólia, configurou-se em Çatal Hüyük - um dos primeiros ambientes urbanos com registro arqueológico -, como a “Grande Mãe” Kybele, e associou-se às principais culturas urbanas fluviais do Oriente-próximo, como a deusa Ishtar, entre o Tigre e o Eufrates, e como Ísis, dentre outras divindades, junto ao Nilo. 
Nos Balcãs, mais precisamente no sudoeste da Macedônia, na região de Bitola e Porodin, objetos de culto à Deusa-Terra, confeccionados em terracota pela cultura VelusinaPorodin, datados no Sexto Milênio, representam divindades femininas com corpo em formato cilíndrico dispostas sobre um modelo arquitetônico, compondo um único objeto, corpo-casa (GIMBUTAS, 1990). No acervo arqueológico atual, essas pequenas deusas de terracota macedônias ocupam um lugar especial, como objetos inaugurais da figuração integrada entre o corpo da mulher e a casa.

A sobrevivência de tal interação é nítida em Cnossos e Arkhanes, na ilha de Creta, nos "naískoi”, pequenos templos de forma cilíndrica em terracota policromada, datados entre 1.300 e 800 a.C., que possuem em seu interior um ícone da deusa Mgua, com os braços erguidos (MERSEREAU, 1993; HÄGG, 2001).

No Grécia e no Egeu, o imaginário da “Grande Deusa” fragmentou-se entre diferentes divindades, especialmente entre Demeter, Hera, Afrodite, Ártemis e Atena. Quanto à Atena, o relevo do friso do Parthenon, na acrópole ateniense, é certamente a mais difundida iconografia na cultura ocidental, referente à procissão de oferendas dedicadas à divindade feminina, protetora das cidades, que se ritualizava ciclicamente nas festividades das Panateneias.

A referida tradição se fragmentou no mundo romano, perpetuando-se, sobretudo, na figura de Ártemis e sua iconografia reinventada em Éfeso, antigo sítio de culto kybeliano.

Perdendo seus atributos típicos nas figuras vermelhas - seu arco e flechas - Ártemis retorna à tradição próximo-oriental de seu vínculo "selvagem” com a natureza bruta e os animais, como "Potnia Theron”, a "Rainha dos animais” (SERVI, 2004). Assim, a Ártemis Efésia é apresentada com o corpo coberto por leões, vacas, cavalos, abelhas, cachos de uvas, e proeminências salientes, interpretadas como testículos de boi, ovos ou seios. Sobre a cabeça, leva uma coroa peculiar em forma de torre ou muralha, atributo derivado das figurações da iconografia frígia da “Deusa Mãe” Cibele (Kybele) que, por sua vez, pode também estar relacionado aos atributos da rainha babilônica Semiramis, esposa de Nimrod, "príncipe dos céus”, idealizador da torre de Babel.

A iconografia de Cibele frígia, em torno do séc. VII a.C., a apresenta tendo sobre a cabeça um objeto alto bastante enigmático, pois tanto pode ser um chapéu, quanto um penteado, um cesto, ou mesmo uma colmeia estilizada. Tal caracterização da "Deusa coroada”, perpetua-se nos relevos votivos áticos, nos “naískoi” da Magna Grécia e, posteriormente, no mundo imperial romano, que a adotou como "Magna mater", conferindolhe a centralidade original das deusas gregas Gaia e Rhea. 
A difusão iconográfica de Cibele, entretanto, retoma a postura tradicional da Kybele de Çatal Hüyük, e a caracteriza como a "Deusa assentada”. Nos “naískoi” gregos, o vínculo dessa deusa com a arquitetura é duplo, como que redundante para ser inequívoco: posicionada sob o frontão triangular de um templo com pilastras nas laterais, ela traz ainda sobre a cabeça uma coroa arquitetônica. Se a coroa não é tão nitidamente arquitetônica na iconografia de Cibele quanto na de Ártemis efésia, nas imagens da Cibele imperial romana ela será evidente, e ganhará destaque como o atributo principal da "Magna mater" divindade geradora que sustenta com seu próprio corpo as arquiteturas, os edifícios da cidade, o templo, a casa.

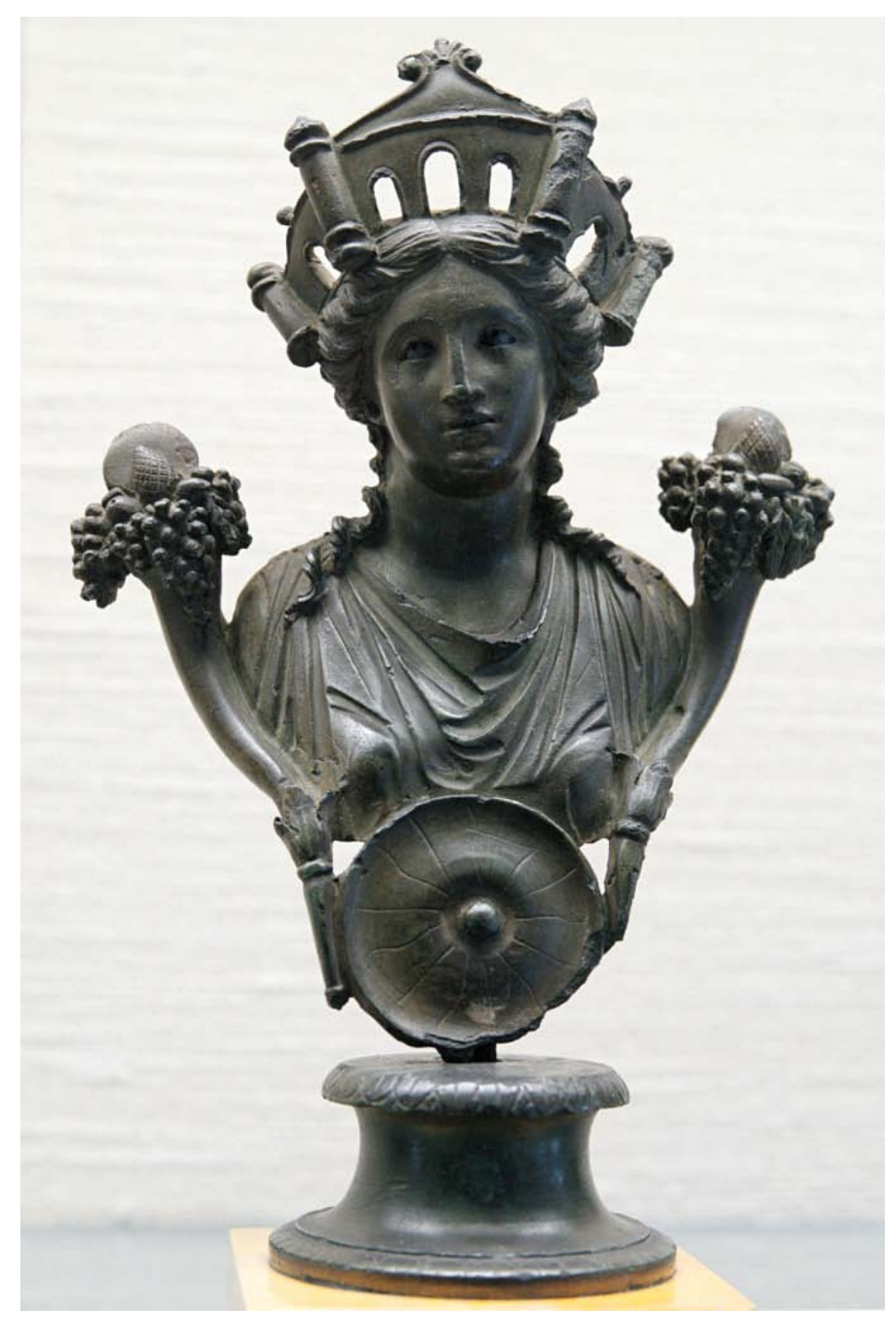

Figura 5 : Busto de Cybele com coroa arquitetônica entre dois cornos de abundância. Bronze gallo-romano, séc. I. Descoberto em Tours, Picardie, c. 1754 . Altura da peça: $19 \mathrm{~cm}$. Fotografia de Marie-Lan Nguyen, com direitos regidos por Wikimedia Commons. Disponível em: <http://commons.wikimedia.org/wiki/File:Cybele_bronze_CdM.jpg>. Acesso em: 27 fev. 2011. 
Dessa figuração e de seus simbolismos, deriva o gestual comum a promesseiros e mestres do Guerreiro, que usam o próprio corpo como amparo de arquiteturas portáteis para fundá-las, amparando-as e ligando-as à terra.

A iconografia de Cibele, coroada com uma arquitetura, desenvolveu-se na Frígia, no interior da Anatólia, e difundiu-se no Mediterrâneo, a partir das franjas da Ásia-menor sobre o Egeu, mais precisamente a partir do grande santuário de Éfeso.

Nesse tradicional local de culto a divindades femininas, conformou-se uma fértil matriz iconográfica original, na confluência da tradição imagética da Grande-Deusa dos animais próximo-oriental, com a tradição figurativa de Cibele frígia, e com a estilização helenística característica dos relevos e estatuária grega. O resultado é uma imagem síntese da “Grande Deusa” - assentada, mas prestes a se levantar, pois tem um pé adiante do outro -, que porta sobre a cabeça a coroa-arquitetura.

Éfeso é o sítio-santuário tradicional, onde se consolida o culto mediterrâneo da divindade feminina geradora, aquela que concebe tudo o que existe. É o lugar do “Artemisium”, na intersecção das tradições próximo-orientais e ocidentais de culto à "Basileis Cosmos” - Rainha do Cosmos -, e também é a sede da passagem mítica e iconográfica dos cultos pagãos a Ártemis/Cibele para o culto cristão à Virgem Maria.

Conforme a tradição católica, S. João Evangelista teria chegado a Éfeso com a Virgem seis anos após a ressureição do Cristo. Nos arredores da cidade-santuário - mais precisamente em Meryemana, a cerca de $8 \mathrm{Km}$ de Selçuk, cidade mais próxima do sítio arqueológico de Éfeso -, Maria teria vivido o resto de seus dias e ali estaria enterrada. Para a crescente Igreja Católica, a sobreposição do culto à Virgem sobre o culto Artemísio na Bacia do Mediterrâneo era bastante conveniente e, informalmente, já se realizava, com base nas várias analogias entre as virtudes comuns às duas deusas. O Terceiro Conselho Ecumênico, em 431, sediado justamente em Éfeso, com a presença do Imperador Teodósio, oficializa tais práticas ao reconhecer oficialmente a Virgem não apenas como a mãe de um Jesus mortal, mas como mãe de Deus (ERDEMGIL, 1994; BOYER, 2000).

A partir de então, abre-se caminho para a formação de um imaginário cristão, que consolidaria uma nova iconografia da grande deusa feminina - ao mesmo tempo tradicional e inovadora -, como a Mãe do mundo cristão. Tal imaginário se afirmaria a partir dos ícones bizantinos de Théotokos, a “Mãe de Deus”, e se desdobraria em diferentes figurações ao longo do tempo, até a imagem de Nossa Senhora de Nazaré, cultuada em Belém do Pará, e as variedades de Deusas-mãe: Nossa Senhora da Conceição, do Rosário, Aparecida. 
O vínculo da Virgem com o modelo arquitetônico, contudo, não será inicialmente evidente no mundo bizantino, como era em Ártemis ou Cibele. O reencontro da Deusa com o modelo de arquitetura será indireto, em meio à iconografia do cortejo, 70 anos depois do Conselho de Éfeso, no mosaico da Basílica Eufrasiana (c.500), em Parenzo/Porec, atual Croácia. Já os “naískoi” voltarão à tona como oratórios, como as Casas Sagradas de Loreto, a partir do séc. XIV (BOYER, 2000), e como os modelos carregados pelos portadores no Círio. Mais longo e sinuoso, sem dúvida, foi o percurso de sobrevivência da coroa pagã de Cibele, reconfigurada nas exuberantes “catedrais” dos mestres do Guerreiro alagoano, e multiplicada nos chapéus dos palhaços, nas coroas das rainhas e nas diademas das "estrelas". Nessa trajetória de longa duração, as deusas mediterrâneas entrelaçaram-se a divindades indígenas e africanas, como expresso nas palavras de Arthur Ramos (2007, p.13):

No Brasil houve uma forte confluência mítica: com as deusas-mães, sereias do paganismo supérstite europeu, as Nossas Senhoras católicas, as iaras ameríndias. Sabemos que, entre nós, as deusas-mães são Nossa Senhora do Rosário (Iemanjá), Nossa Senhora da Conceição (Iemanjá e Oxum), etc. Já tivemos ocasião de mostrar qual leitmotiv interliga essas várias concepções, onde três crenças principais se puseram em contato.

No contexto urbano de Belém do Pará, de Maceió e de outras cidades alagoanas, em pleno séc. XXI, com os promesseiros e figurantes do Guerreiro, Cibele e Ártemis voltam à cena reinventadas como "Rainhas da Amazônia”, e paradoxais "Virgens da Concepção”, fundamentando, simbolicamente, todo e qualquer fazer técnico, toda atividade artística, toda ação que transforme uma condição natural e promova uma cosmogonia arquitetônica, o surgimento da "pólis”. Tais vínculos cosmogônicos promovem uma convergência simbólica entre as pequenas moradias na periferias das metrópoles, os oratórios, as capelas e igrejas, enfim, promovem um ampliação do espaço urbano em um sentido universal, como exposto por Argan (1992):

"São espaço urbano o pórtico da basílica, o pátio e as galerias do palácio público, o interior da igreja. Também são espaço urbano os ambientes das casas particulares; e o retábulo sobre o altar da igreja, a decoração do quarto de dormir ou da sala de jantar, até o tipo de roupa e de adornos com que as pessoas andam, representam seu papel na dimensão cênica da cidade. Também são espaço urbano, e não menos visual por serem mnemônicosimaginárias, as extensões da influência da cidade além dos seus limites: a zona rural, de onde chegam os mantimentos para o mercado da praça, e onde o citadino tem suas casas e suas propriedades, os bosques onde ele vai caçar, o lago ou os rios onde vai pescar; e onde os religiosos tem seus mosteiros, e os militares suas guarnições. O espaço figurativo, como demonstrou muito 
bem Francastel, não é feito apenas daquilo que se vê, mas de infinitas coisas que se sabem e se lembram, de notícias. Até mesmo quando pinta uma paisagem natural, um pintor está pintando, na realidade, um espaço complementar do próprio espaço urbano.” (p.43-44).

\title{
BelÉM do PARÁ, MACEIÓ, AND THE SURVIVAL OF THE “ARCHITECTURAL MODEL HOLDERS"
}

\begin{abstract}
This article presents an ongoing research, supported by $\mathrm{CNPq}$ (Conselho Nacional de Desenvolvimento Científico e Tecnológico) and by the Pró-reitoria de Pesquisa of the Universidade de São Paulo, about the interactions between the expressions of the promise keepers of the Círio of Nazareth at Belém of Pará, the "Warriors" players of the Alagoan Christmas-auto and the universe of architectural scale models, understood as objects with small size and architectural shape. This study deals, more precisely, with the interactions of those expressions with the "artistic motif of the architectural model holder", a typical medieval figuration that features a character holding a small size object with architectural forms, as a scale model. Over these urban cultural goods, the proposed approach is based on the notion of "survival", "nachleben" or "survivance", on the understanding of long-term phenomena deeply rooted in the collective memory, and also on the concept of "pathosformeln". In methodological terms this research proposes a visual and anthropological approach to the mentioned phenomena, contextualizing and articulating them to imaginary universe of architectural representations.
\end{abstract}

Key-words: Representations. Imaginary. Architecture. Architectural Models.

\section{REFERÊNCIAS}

ALVES, I. O carnaval devoto - um estudo sobre a festa de Nazaré, em Belém. Petrópolis: Vozes, 1980.

ARGAN, G.C. A História da Arte. In: História da Arte como História da Cidade. São Paulo: Martins Fontes, 1992.

AZEVEDO, J. (coord.). Círios de Nazaré. Belém: Graphitte, 2000.

Círio de Nazaré: a festa da fé como comunhão solidária - uma análise teológica a partir da concepção de fé de Juan Luis Segundo. Belo Horizonte: FAJE, 2008. Tese (Doutorado). Prog. de Pós-graduação em Teologia, FAJE, BH, 2008.

BADAWY, A. A Monumental gateway for a Temple of King Sety I: An Ancient Model Restored. Miscellanea Wilbouriana, 1, Nova Iorque, The Brooklyn Museum, p.1-20, 1972.

BARATA, M. Apontamentos para as Efemérides Paraenses. Revista do Inst. Hist. e Geo. Brasileiro, 1921.

BARROS, L. G. DE. A Batalha de Oliveiros com Ferrabrás. São Paulo: Editora Luzeiro Limitada, sem data.

BONNA, M. K. Círio: Painel de Vida. Belém do Pará: Falangola Editora, 1986. 
BOYER, M.-F. Culto e imagem da Virgem. São Paulo: Cosac \& Naify, 2000.

BRANDÃO, Théo. Folguedos natalinos - Guerreiro. Coleção Folclórica da UFAL. Maceió: Imprensa Universitária da UFAL, 1976.

. Folguedos Natalinos. Maceió: Museu Théo Brandão, UFAL, 2003.

. O Reisado Alagoano. Maceió: EDUFAL, 2007.

BRAUDEL, F. Escritos sobre a história. São Paulo: Perspectiva, 1992.

CASCUDO, Câmara. Dicionário do Folclore Brasileiro. Rio de Janeiro: Editora Tecnoprint S.A., 1954.

CÍRIO DE NAZARÉ. Dossiê IPHAN; I. Rio de Janeiro: IPHAN, 2006

CONTARDI, Bruno. Prefácio. In: ARGAN, G.C. História da Arte como História da Cidade. São Paulo: Martins Fontes, 1992.

DIDI-HUBERMAN, G. L'image survivante. Histoire de l'art et temps des fantômes selon Aby Warburg. Paris : Minuit, 2002.

DUARTE, Abelardo. Folclore Negro das Alagoas. Maceió: Imprensa Universitária da UFAL, 1975.

ELIADE, M. O Sagrado e o Profano, a essência das religiões. São Paulo: Martins Fontes, 2001.

ERDEMGIL, S. Ephesus: ruins and museum. Istambul: Net Turistic Yayinlar, 1994.

FIGUEIREDO, S.L., org. Círio de Nazaré: festa e paixão. Belém do Pará: EDUFPA, 2005.

FILHO, Savio Capelossi; SEYNAEVE, Raymond J.M. Guia Histórico e Turístico da Cidade de Belém. Belém: CEJUP, 1992.

GIMBUTAS, M. The Goddesses and Gods of Old Europe - 6500 a.C. - 3500 a.C. Myths and Cult Images. University of California Press Berkeley and Los Angeles, 1990.

HÄGG, R. The Minoan hut-models: their origin and function reconsidered. In: "MAQUETTES Architecturales” De L’AnTiQuite. Actes du Colloque de Strasbourg, 1998. Paris: De Boccard, 2001. p.357-361.

KALAYAN, H. Notes on assembly marks, drawings and models concerning the Roman period monuments in Lebanon, In: Annales Archéologiques Arabes Syriennes. Revue d'Archéologie et d'Histoire, 21, 1971, p.269-273.

LÉVI-STRAUSS, C. La pensée sauvage. Paris: Plon, 1962.

LIPSMEYER, E. The donor and his church model in medieval art from early christian times to the late romanesque period. Diss. State Univ., New Brunswick, N. J. 1981.

LOUREIRO, J. de J. P. Cultura Amazônica: uma poética do imaginário. São Paulo: Escrituras Editora, 2001. 
MAUÉS, R. H. Padres, pajés, santos e festas: catolicismo popular e controle eclesiástico. Belém: Cejup, 1995.

Belém: Cejup, 1999.

Uma outra "invenção" da Amazônia: religiões, histórias, identidades.

Histórico do Círio de Nazaré. In: AZEVEDO, Josimar (coordenador)

Círios de Nazaré. Belém: Graphitte, 2000.

MERSEREAU, R. Cretan cylindrical models, abstract. American Journal of Archeology, Boston, n.97, p.1-47, Janeiro, 1993.

MONTARROYOS, H. Festas profanas e alegrias ruidosas: a imprensa no Círio. Belém: Falangola Editora, 1991-1993.

MOREIRA, Eidorfe. Visão geo-social do Círio. Belém: Imprensa Universitária, 1971.

PANTOJA, V. Negócios sagrados: reciprocidade e mercado no Círio de Nazaré. Belém: UFPA, 2006. 135 p. Dissertação (Mestrado). Prog. de Pós-graduação em Ciências Sociais, área de concentração em Antropologia, UFPA, Belém do Pará, 2006.

PANTOJA, V.; MAUÉS, R.H. O Círio de Nazaré na constituição e expressão de uma identidade regional amazônica. Revista Espaço e Cultura, Rio de Janeiro, UERJ, n.24, p.5768, jul./dez. 2008.

PEDROSA, Tânia de Maya. Arte Popular de Alagoas. Maceió: Grafitex, 2000.

PERALTA, P.P. As narrativas fotográficas de Marcel Gautherot: estudo visual do guerreiro alagoano e do bumba-meu-boi maranhense. Revista Arte\&Ensaios, Rio de Janeiro, PPGAVEBA/UFRJ, n.15, p.34-39, 2007.

QUINTELLA, Gustavo (Org.). A parte do Índio Peri do Guerreiro, avisos, peças e embaixadas em partitura segundo D.Vitória e Mestre Verdelinho, transcrito por Gustavo Quintella. Maceió: Victória Gráfica, 2000.

RAMOS, Arthur. Estudos de Folk-lore - Definições e limites, teorias de interpretação. Rio de Janeiro: Livraria-Editora da Casa do Estudante do Brasil, 1951.

WMF Martins Fontes, 2007.

. O folclore negro do Brasil: demopsicologia e psicanálise. São Paulo:

ROCHA, José Maria Tenório. Folclore Brasileiro: Alagoas. Rio de Janeiro: FUNARTE, 1977.

ROCQUE, C. História do Círio e da Festa de Nazaré. Belém do Pará: Mitograph Editora Ltda., 1981.

ROZESTRATEN, A.S. A Estudo sobre a história dos modelos arquitetônicos na Antiguidade. São Paulo: FAUUSP, 2003. 283 p. Dissertação (Mestrado). Programa de Pós-graduação em Arquitetura e Urbanismo, área de concentração História e Fundamentos da Arquitetura e Urbanismo, FAUUSP, São Paulo, 2003. 
. A iconografia do portador do modelo de arquitetura na arte medieval. São Paulo: FAUUSP, 2007. 165 p. Tese (Doutorado). Programa de Pós-graduação em Arquitetura e Urbanismo, área de concentração História e Fundamentos da Arquitetura e Urbanismo, FAUUSP, São Paulo, 2007.

SAINTYVES, P. As Virgens Mães e os nascimentos miraculosos. Tradução de Gastão Pereira da Silva. Rio de Janeiro: Livraria Império Editora, 1960.

SEGALA, L. A coleção fotográfica de Marcel Gautherot. Anais do Museu Paulista. São Paulo. N. Sér. v.13. n.2. p. 73-134. jul.- dez. 2005.

SERVI, K. Mythologie Grecque. Athènes: Ekdotike Athenon S.A., 2004.

ThesCRA - Thesaurus Cultus et Rituum Antiquorum. Los Angeles: J.P. Getty Museum, 2004.

TYLOR, E.B. Primitive culture: researches into the development of mythology, philosophy, religion, language, art and custom. Vol. 1. Londres: H.Murray, 1873.

VIANNA, A. Festas populares do Pará. Annaes da Biblioteca e Arquivo Público do Pará, t. III. Belém, 1904.

WARBURG, A. The Renewal of Pagan Antiquity. Los Angeles: The Getty Institute, 1999.

WILL, E. La maquette de l'adyton du temple A de Niha (Beqa). In: LE DESSIN D'ARCHITECTURE DANS LES SOCIETES ANTIQUES. Anais do colóquio de Strasbourg, 26-28 de Janeiro de 1984. Strasbourg: Université des Sciences Humaines de Strasbourg, Centre de Recherche sur le Proche-Orient et la Grèce antiques, 1985. p.277-281.

Recebido em: 28/02/2011

Aprovado em : 09/05/2011 